\title{
PENGUATAN KAPASITAS KLASTER USAHA KECIL DAN MENENGAH: KASUS DI SERENAN, KLATEN
}

\author{
Fereshti, N.D ${ }^{1}$ \\ Edy Purwo Saputro ${ }^{1}$ \\ Didit Purnomo ${ }^{1}$ \\ ${ }^{1}$ Fakultas Ekonomi Universitas Muhammadiyah Surakarta, Jawa Tengah \\ E-mail: edypsums@plasa.com; didiet_p@yahoo.com
}

\begin{abstract}
This study aims at examining a basic and optimal strategy for strengthening an export-based UKM cluster at Serenan Klaten. This research sample is UKM bases on export in Serenan, Klaten. Reason of location choice in Serenan because Serenan has been specified to become one of UKM cluster to base on export by government. It used a qualitative approach with the identification of the export-based UKM's characteristics. This included firm size, asset, planning, marketing, personnel, value of access to information and performance. In this research applied SWOT analysis to formulate strategy develops UKM in Serenan Klaten. There are seven strategies formulated to develop UKM in Serenan Klaten
\end{abstract}

Key words: cluster, export, business strategy, SWOT

\section{PENDAHULUAN}

Usaha kecil dan menengah (UKM) merupakan salah satu kekuatan ekonomi terdepan. Oleh karena itu UKM merupakan aspek penting dalam pembangunan ekonomi (Akita, dan A. Alisjahbana, 2002). Dalam haluan negara secara jelas telah digambarkan peran ekonomi kerakyatan yang berbasis UKM (Aminudin, 2003 dan Devarajan, 2002). dibanding dengan negara maju, Indonesia kehilangan kelompok industri menengah dalam struktur industri. Akibatnya di satu sisi terdapat sejumlah kecil perusahaan besar dan di sisi lain melimpahnya usaha kecil yang berorientasi pasar domestik (Ayyagari, 2003). Propinsi Jawa Tengah sebagai bagian dari sentra pengembangan UKM berbasis ekspor secara tak langsung juga berkepentingan untuk menentukan perencanaan strategis bagi pengembangan UKM berbasis ekspornya (Gradstein, 2003).

Rumusan masalah penelitian ini yaitu pertama: apakah basis penguatan klaster UKM yang berorientasi ekspor sudah optimal dan kedua: bagaimana strategi optimalisasinya?

Tujuan dalam penelitian ini yaitu untuk mengetahui basis penguatan klaster UKM yang berorientasi ekspor dan bagaimana strategi optimalisasi. Adapun manfaat penelitian ini yaitu untuk lebih mengetahui basis penguatan klaster UKM yang berorientasi ekspor dan bagaimana strategi optimalisasi. 
Pencapaian tujuan substitusi impor dan promosi ekspor tidak akan terealisir melalui pengembangan UKM, jika UKM tidak dibantu mengembangkan efisiensi teknologi yang memungkinkan mereka untuk bersaing secara efektif. Oleh karena itu, langkah yang tepat jika dikembangkan teknologi tepat guna yang berbasis sumberdaya lokal karena pertama: membutuhkan modal yang kecil, kedua: cocok diterapkan di negara berkembang yang masih lemah dan ketiga: mampu melepaskan diri dari ketergantungan terhadap teknologi impor. Industri UKM harus didorong untuk berkembang di pedesaan dan kota-kota kecil. Hal ini akan mengurangi perbedaan dan ketimpangan pendapatan secara regional, mereduksi konsentrasi penduduk di kota, meningkatkan pendapatan dan standar hidup, serta akan lebih memeratakan pendapatan dan kesejahteraan. Esensi atas semua acuan itu terkait dengan program pemberdayaan ekonomi riil kerakyatan yang digalakkan pemerintah (Murphy, 2000).

Peran UKM masih rendah dalam perekonomian daerah disebabkan akses pendanaan sulit, meski sudah ada skim kredit, kesulitan memperoleh bahan baku dan pemasaran produk UKM terdapat pada pasar lokal, belum siap menghadapi persaingan era global, masih rendahnya akses sumber informasi (pasar, teknologi, dan desain) dan juga rendah penguasaan teknologi (Nasution, 2003).

Program-program promosi klaster dipandang lebih menguntungkan dibanding dengan program-program usaha-usaha individual, tidak hanya karena efisiensi biaya, tapi juga ekonomi eksternal yang memberi rentang keuntungan bagi klaster. Usaha-usaha klaster dapat memperoleh berbagai keuntungan yang bisa ditingkatkan dan juga diperluas jika mereka aktif meneruskan. Sebagai contoh, pemusatan geografis UKM-UKM dalam klaster akan bisa meningkatkan kesadaran usaha-usaha memasok produk-produk yang diperlukan. UKM pada klaster kemudian berada pada posisi yang lebih menguntungkan untuk mendapatkan pesanan. Pemasaran dan pembelian bersama merupakan contoh tipikal tindakan-tindakan kolektif. Dalam upaya lebih meningkatkan kapasitas kolektif UKM-UKM dalam klaster, maka pertalianpertalian intern disamping juga pertalianpertalian ekstern dengan pihak yang berkepentingan di luar hendaknya dipromosikan (Sallatu dan Suhab, 2003).

\section{METODE PENELITIAN}

\section{Penelitian Sebelumnya}

Penelitian tentang UKM sangat beragam dan masing-masing mengacu pada model yang berbeda. Penelitian Aminudin (2003) menjelaskan bahwa industri kecil yang berkembang di Yogya mampu mendukung pengembangan wilayah. Bahkan, sektor industri kecil juga berperan dalam penyerapan tenaga kerja, kontribusi terhadap nilai ekspor, dan nilai PDRB. Meski demikian kemampuan pembentukan nilai tambahnya masih sangat terbatas.

Penelitian Sugarmansyah, dkk (2003) menjelaskan tentang peran difusi teknologi bagi eksistensi UKM untuk kasus pengecoran di Ceper, Klaten. Keberhasilan difusi inovasi teknologi dipengaruhi beberapa elemen penting yang perlu dipertimbangkan yaitu (1) inovasi teknologi yang didifusikan harus memiliki manfaat bagi adopters (relative advantage), meskipun juga perlu dianalisis aspek compatibility, complexity, trialability, dan observability; (2) bagaimana inovasi 
tersebut dikomunikasikan; (3) difusi inovasi teknologi memerlukan waktu yang relatif beragam dan; (4) harus mempertimbangkan sistem sosial yang ada.

Penelitian Suriadinata, dkk (2001) yang menjelaskan tentang penggunaan teknologi informasi dan komunikasi bagi UKM yang berorientasi ekspor di Indonesia secara detail menunjukkan bahwa kebutuhan terhadap aplikasi tersebut sudah tidak bisa lagi ditawar sebab ada kemanfaatan makro yang bisa diperoleh, terutama dalam proses kecepatan akses informasi dan transaksi. Adapun kasusnya kasus di Medan, Bandar Lampung, Jakarta, Bandung, Yogyakarta, Surabaya, Denpasar, dan Makasar.

Penelitian Sanusi (2004) yang menjelaskan tentang tingginya parokialism institusi dengan kasus pengembangan koperasi dan UKM Indonesia menggambarkan secara konkret tentang berbagai kendala yang ada. Meski demikian, prospek terhadap arah ke depan tetap ada dan tentunya butuh komitmen dari semua pihak, terutama yaitu dari pihak pemda atau pemkot sebagai fasilitator.

Penelitian Rahayu (2005) yang menganalisis tentang peran modal ventura terhadap eksitensi UKM menghasilkan kesimpulan yaitu, pertama: meski implementasi pola kemitraan dengan menggunakan pembiayaan modal ventura telah berlangsung sejak tahun 1973, tetapi formalisasi usaha modal ventura baru terjadi sejak ditetapkannya Kepres No. 61 Tahun 1988; kedua: usaha modal ventura merupakan pola kemitraan alternatif melalui bagi hasil dan risiko yang dimaksudkan untuk menunjang upaya peningkatan dan pengembangan UKM dan koperasi di Indonesia; ketiga: peranan penyertaan modal ventura dalam mendorong UKM secara keseluruhan menunjukkan penurunan jumlahnya, tapi secara khusus jumlah UKM yang terbantu makin banyak, dan keempat: peran modal ventura dalam mendorong UKM masih sangat kecil yaitu masih sekitar 1,5 persen dari total peranan UKM, sementara UKM sebagai salah satu daya tahan perekonomian sangat diperlukan dalam pertumbuhan perekonomian.

\section{Jenis Penelitian}

Sesuai perumusan dan tujuan penelitian, maka jenis penelitian ini yaitu eksplanatori atau penelitian penjelasan. Acuan utama dalam penelitian eksplanatori adalah sistem pengembangan strategi yang mengacu kepentingan jangka panjang. UKM yang berbasis ekspor dalam model pengembangan klaster juga butuh pendekatan strategi yang handal agar mampu bersaing di era global. Klaster UKM berbasis ekspor di Serenan, Klaten sangat membutuhkan pendekatan strategis untuk pengembangan lebih lanjut.

\section{Sampel}

Sampel penelitian ini adalah 30 UKM berbasis ekspor di Serenan, Klaten. Alasan pemilihan lokasi di Serenan karena Serenan telah ditetapkan menjadi salah satu klaster UKM berbasis ekspor oleh pemerintah. Kelemahan dari teknik ini yaitu pada generalisasi hasil namun kelemahan ini dapat diatasi dengan penggunaan sampel yang jumlahnya cukup besar yaitu minimal 30 . Pemilihan sampel penelitian ini diharapkan bisa mewakili kondisi karakteristik UKM berbasis ekspor di Serenan, Klaten secara umum. Selain itu, konsekuensi atas penyerapan tenaga kerja oleh klaster UKM berbasis ekspor di Serenan sangat terkait dengan perbaikan pendapatan perkapita masyarakat. Kriteria pemilihan sampel berdasar nilai 
ekspor yang terbesar dari kumulatif 5 tahun terakhir. Konsekuensi pemilihan sampel ini memberi kompleksitas permasalahan yang dihadapi UKM dalam proses produksi.

\section{Pengumpulan Data}

Pengumpulan data dilakukan dengan kuisioner (tertutup). Secara spesifik, kuisioner mencakup informasi umum yang terkait dengan karakteristik: firm size, permodalan, perencanaan, pemasaran, produksi, personalia, akses informasi dan kinerja ekspor. Untuk memperoleh gambaran lebih lengkap tentang klaster UKM berbasis ekspor dilakukan dengan pendalaman interview kepada pemilik dan pekerja, juga pihak terkait, khususnya Disperindag di Klaten, dan atau di tingkat Jawa Tengah.

\section{Model Penelitian}

Model penelitian yang dipakai lebih terfokus pada upaya untuk mengetahui beragam karakteristik dan peluang - ancaman klaster UKM berbasis ekspor sehingga memungkinkan dalam upaya untuk mengetahui strategi pengembangannya untuk mendukung dan meningkatkan kinerja UKM berbasis ekspor dalam dimensi makro. Model penelitian ini diilustrasikan dalam Gambar 1.

\section{Analisis Data}

Penekanan analisis dalam penelitian ini menggunakan pendekatan kualitatif. Untuk mendukung hasil yang optimal melalui pendekatan kualitatif, maka prosedural analisis data dalam penelitian ini mengacu pada beberapa tahap yaitu:

Pertama: melakukan identifikasi semua kelompok klaster UKM berbasis ekspor di Serenan, Klaten yang bisa dilakukan dengan mengacu data sekunder dari BPS (Jawa Tengah dalam angka) dan atau data dari Kanwil Deperindag. Mengacu sumber Kanwil Perindustrian Jawa Tengah, klasifikasi UKM di Jawa Tengah dikelompokkan dalam empat bidang, industri logam, mesin dan elektronika, industri kimia, industri aneka, dan industri hasil pertanian. Orientasi penentuan sampel lebih ditekankan pada nilai hasil produksi dan nilai ekspor yang terbesar dalam 5 tahun terakhir.

Kedua: menentukan jumlah sampel dari kla-

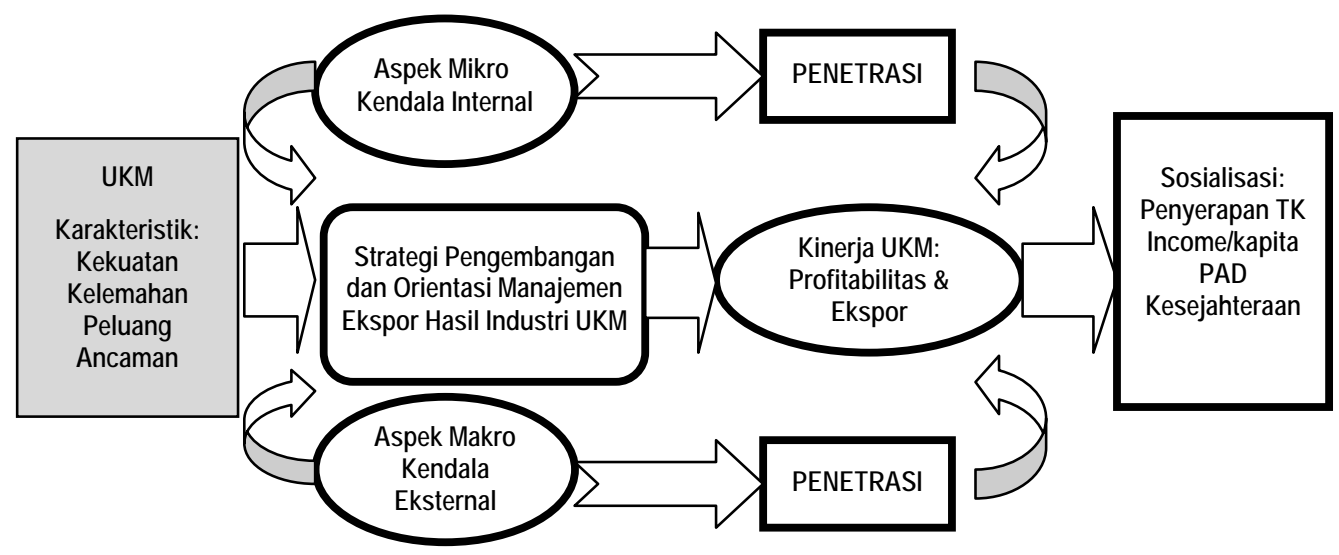

Gambar 1. Keterkaitan Strategi Pengembangan terhadap Kinerja UKM Berbasis Ekspor 
sifikasi UKM berbasis ekspor yang memenuhi kriteria nilai produksi dan nilai ekspor terbesar dalam 5 tahun terakhir. Penentuan sampel lebih mengacu pada kuantitas penyerapan TK (implikasi perbaikan income masyarakat). Sampel yang dipakai adalah 30 yang diharapkan mewakili karakteristik UKM berbasis ekspor. Kriteria pemilihan sampel didasarkan nilai hasil produksi dan nilai ekspor yang terbesar dari kumulatif 5 tahun terakhir ini sehingga hanya industri yang masuk kriteria nilai hasil produksi dan ekspor terbesar saja yang dipakai sebagai sampel untuk mewakili karakteristik UKM berbasis ekspor.

Ketiga: setelah dipilih sampel, selanjutnya penyebaran kuisioner. Secara spesifik, kuisioner yang diberikan kepada 30 sampel mencakup nilai karakteristik firm size, aspek permodalan, aspek perencanaan, pemasaran, permodalan, dan aspek personalia, akses informasi, serta kinerja ekspornya. Selain itu, untuk memperoleh gambaran yang lebih lengkap tentang latarbelakang UKM dilakukan dengan cara pendalaman interview kepada pemilik dan pekerja (serta pihak terkait untuk lebih mengetahui tentang karakteristik dan juga permasalahan yang sebenarnya dihadapi UKM berbasis ekspor di Jawa Tengah).

Keempat: dari berbagai permasalahan yang dikumpulkan, baik itu melalui kuisioner maupun interview kemudian dilakukan analisis dengan mengacu pada teoritis aspek dan fungsi manajemen (ACUAN ANALISIS STRATEGI). Dalam hal ini nantiya dapat diformulasikan suatu strategi pengembangan manajeman bagi UKM berbasis ekspor. Implikasi terhadap strategi itu diharapkan bisa meningkatkan klaster kinerja UKM yang berbasis ekspor yang sekaligus akan memacu perekonomian daerah (PAD), serta kinerja ekspor nasional.

\section{HASIL PENELITIAN DAN PEMBAHASAN}

\section{Identifikasi Sampel}

Sampel penelitian 30 UKM berbasis ekspor di Serenan, Klaten dan diambil secara acak. Tidak ada data UKM di Serenan yang melakukan ekspor langsung karena hampir mayoritas adalah sub-ekspor. Oleh karena itu, banyak pelaku UKM di Serenan yang tidak tahu total ekspor yang terjadi dalam periode 5 tahun terakhir. Pengumpulan data dilakukan dengan kuisioner yang mencakup informasi terkait karakteristik: (1) firm size, (2) permodalan, (3) perencanaan, (4) pemasaran, (5) produksi, (6) personalia, (7) akses informasi, dan (8) kinerja ekspor.

Mayoritas sampel UKM di Serenan, Klaten adalah beroperasi lebih dari 10 tahun yaitu mencapai 23 buah (77 persen) dan kepemilikan didominasi oleh pria yaitu 22 buah (73 persen). Yang dimaksud dengan kepemilikan yaitu mereka yang bekerja penuh mengurus UKM dan sesuai dengan akte pendirian yang ada. Meskipun demikian, ada juga UKM yang dimiliki oleh perempuan yaitu 8 buah (27 persen). Dari jumlah ini ternyata 5 orang berstatus sebagai penerus dari usaha yang telah dirintis orang tua atau suami. Secara umum, UKM adalah berstatus sebagai usaha yang dirintis sejak awal yaitu 25 buah (83 persen). Dari gambaran ini secara tidak langsung menunjukkan bahwa eksistensi UKM di Serenan bisa berkembang terutama dikaitkan dengan banyaknya sampel UKM yang telah beroperasi lebih dari 10 tahun (pascakrisis). Yang menarik ternyata mayoritas UKM tersebut tidak mempunyai 
website sebagai salah satu alternatif promosi secara global yaitu mencapai 21 buah (70 persen).

UKM yang telah mempunyai website ternyata tidak serius melakukan upload terhadap isi website-nya sebab selama diakses yaitu tanggal 2 sampai dengan 20 Januari 2008 pada jam kerja ternyata tidak ada perubahan sama sekali atas isi website-nya. Ini sangat disayangkan sebab dalam kapasitas sebagai klaster UKM semestinya ada orientasi terhadap target pemasaran secara global. Dari kondisi yang demikian, maka pemakaian tenaga kerja lebih banyak mengandalkan pada pemesanan sehingga ketika ada pesanan maka tenaga kerja yang ada meningkat lebih dari 10 orang, tapi ketika tidak ada maka tenaga kerja harian rata-rata kurang dari 10 orang.

Dari 30 sampel UKM yang diambil dan merujuk hasil kuesioner, ditabulasikan dalam Tabel 1.

\section{Tabel 1. Data Karakteristik UKM Sampel Penelitian}

$\begin{array}{lll}\text { Karakteristik } & \text { 1. Umumnya berskala kecil, tradisional dan cenderung konstan setiap tahunnya } \\ \text { Firm Size } & \text { 2. } \begin{array}{l}\text { Mayoritas tidak berbadan usaha yang sempurna, meski ada sebagian yang telah } \\ \text { menerapkannya }\end{array} \\ & \text { 3. Ada yang baru berdiri (<10 tahun), tetapi ada juga terusan dari orang tua atau } \\ \text { pendahulunya }\end{array}$

Karakteristik Perencanaan

1. Belum punya perencanaan spesifik untuk kepentingan jangka panjang, meski sadar akan hal itu

2. Perencanaan yang ada sering bersifat intuisi dan cenderung melemah karena keterbatasan modal. Di sisi lain, model sub-ekspor cenderung merujuk pada kemauan eksportirnya atau pengepulnya

3. Konsekuensi yang terjadi yaitu tidak ada proses untuk ekspansi bisnis secara sistematis - kontinu

4. Tidak ada respons positif jika terjadi penguatan permintaan atas pesanan eksportir (minim perencanaan dan modal) dan biasanya dialihkan kepada pengusaha yang lain

5. Muncul perencanaan yang bersifat kolektif (sentra industri) yang secara umum terkait dengan pesanan atas produk-produk tertentu dari pengepul atau eksportir dari Jakarta - Jogjakarta 
Karakteristik Pemasaran

Karakteristik Produksi

Karakteristik Personalia

Karakteristik

Akses Informasi
1. Bersifat tradisional yang mengandalkan promosi "getok tular" (dari mulut ke mulut) untuk lebih mendukung pemasaran. Meski ada website tapi tidak optimal memanfaatkannya

2. Tidak ada perencanaan promosi yang berkelanjutan karena keterbatasan modal dan tradisional. Pembuatan website tidak maksimal dan tidak dimaksimalkan

3. Tak jarang pesanan datang secara kebetulan karena konsumen melihat produk dipasaran atau mengandalkan informasi dari mulut ke mulut. Pesanan seperti ini biasanya tidak banyak

4. Untuk produk pesanan biasanya merupakan order yang dikerjakan dalam sentra industri (atau yang menjadi binaan dari mitra bisnisnya - eksportir - pengepul)

5. Aspek lokasi juga menjadi batasan bagi proses pemasaran, meski ini tidak mutlak

1. Ada yang bersifat pesanan yaitu terutama dari order eksportir tetapi ada juga yang tidak berdasar pesanan (meski produksi jenis ini tidak terlalu besar)

2. Untuk pesanan biasanya tipe dan jenis produk sudah standar sesuai permintaan dari mitra bisnis (program kemitraan) atau eksportir yang membawa contoh. Kualitas kontrol sangat ketat dan tak jarang banyak terjadi retur barang yang secara otomatis merugikan

3. Untuk order yang tidak pesanan biasanya tergantung pada permintaan pasar yang bisa sedikit ditangkap oleh mereka. Untuk jenis ini tidak jarang meniru tipe - jenis dari produk pesanan (dari mitra binaan atau pengepul atau eksportir) atau retur produk yang kemudian disebut juga sebagai sisa ekspor)

4. Peralatan yang sederhana sangat berpengaruh terhadap kemungkinan inovasi produk secara berkelanjutan

5. Tidak ada inovasi yang radikal terhadap proses produksi, semuanya berjalan sesuai apa adanya (cenderung reaktif terhadap kemungkinan inovasi produk)

1. Cenderung mengutamakan peran keluarga secara menyeluruh. Aspek profesionalisme seperti yang ada dalam organiasi formal tidak muncul dan cenderung tidak berkembang

2. Ikatan kekeluargaan sangat kental sehingga bisa berakibat positif tapi juga menjadi ancaman serius jika terjadi konflik

3. Tidak ada aturan yang jelas dan spesifik terhadap diskripsi pekerjaan, semuanya tergantung pada kesiapan masing-masing untuk bekerja sesuai kesempatan yang ada pada saat itu

4. Semua harus bertanggungjawab terhadap kualitas produk, pemasaran, produksi, perencanaan dan terutama kelangsungan hidup usaha

5. Pengambilan keputusan bersifat menyeluruh karena tidak adanya pimpinan yang definitif dalam proses personalia (konsekuensi dari sistem kekeluargaan)

1. Tak ada akses informasi, meski ada cenderung lemah dan tidak memanfaatkan secara total. Padahal, internet bisa dimanfaatkan untuk membuka peluang lebih terbuka, termasuk juga tujuan ekspor ke luar negeri

2. Akses informasi ke pasar cenderung labil karena mengandalkan informasi dari mulut ke mulut serta ketergantungan terhadap pengepul atau eksportir yang dominan.

3. Ketiadaan akses informasi berakibat pada lemahnya proses perencanaan. Bahkan kalaupun ada akses informasi ternyata hanya sebatas informasi yang tidak akurat bagi pengembangan usaha

4. Informasi tentang peraturan perundangan tidak banyak dimanfaatkan yang kemudian justru memperlemah posisi dan eksistensi mereka

5. Ada kesadaran terhadap informasi, tapi tidak ada komitmen untuk memanfaatkan secara penuh 
Karakteristik Kinerja Ekspor
1. Mayoritas sangat tergantung kepada pengepul atau eksportir dan tidak ada usaha untuk mampu menembus langsung pasar ekspor

2. Logika yang ada karena dengan ada pengepul atau eksportir maka jaminan terhadap pembayaran bisa lebih kuat dibanding dengan melakukan ekspor sendiri (ini terutama terjadi karena banyak kasus larinya buyer, sementara produk sudah terkirim dan biaya produksi sudah dikeluarkan)

3. Terkait itu, maka kalaupun ada pinjaman perbankan maka pihak pengepul atau eksportir ikut memberikan personal guarantee dan ini memberikan kepastian bagi mereka untuk berproduksi

4. Beberapa memang sudah sering mengikut pameran di kota-kota besar terutama untuk menarik buyer asing demi tujuan ekspor secara periodik, namun ketakutan atas larinya buyer masih kuat membayangi keputusan untuk menerima order secara langsung kepada buyer asing

5. Sudah ada koordinasi binaan dari dinas terkait, baik di daerah, wilayah ataupun pusat dalam menjembatani promosi ekspor, meski realisasinya masih belum sepenuhnya maksimal

Sumber: data primer diolah

\section{Analisis Strategi UKM Berbasis Ekspor}

Mengacu pada urgensi analisis strategi terhadap manfaat makro penumbuhkembangan UKM di daerah, terutama yang berbasis ekspor, maka perlu ada model pengembangan ekonomi di daerah melalui pemberdayaan UKM. Oleh karenanya dalam perumusan kebijakan makro ekonomi di daerah adalah dengan memperhatikan beberapa hal berikut:

a. Memberdayakan UKM dan juga koperasi agar lebih efisien, produktif dan berdaya saing dengan menciptakan iklim berusaha yang lebih kondusif dan peluang usaha seluas-luasnya. Bantuan pemerintah bisa diberikan selektif terutama dalam bentuk perlindungan dari bentuk persaingan yang tidak sehat, pendidikan dan latihan, informasi bisnis dan teknologi, permodalan, dan lokasi berusaha, serta bahan baku.

b. Mengembangkan dukungan pola kemitraan dalam bentuk keterkaitan usaha yang saling menunjang dan mengun- tungkan antara koperasi, swasta dan BUMD, serta antarusaha besar, menengah dan kecil untuk memperkuat struktur ekonomi.

c. Meningkatkan penguasaan, pengembangan, dan juga pemanfaatan iptek, termasuk teknologi dalam negeri terutama UKM untuk meningkatkan daya saing produk yang berbasis sumber daya lokal dan berorientasi ekspor.

d. Menumbuhkembangkan potensi rantai nilai yang terbangun secara sistematis dan integratif. Langkah ini dilakukan dengan mengacu pada semua potensi sumber daya lokal dan berorientasi pada pasar ekspor dengan tanpa mengabaikan semua potensi sumber daya yang terbarukan. Dengan demikian langkah ini memungkinkan UKM untuk terus melakukan ekspansi yang memberikan manfaat makro (lihat Gambar 1) 


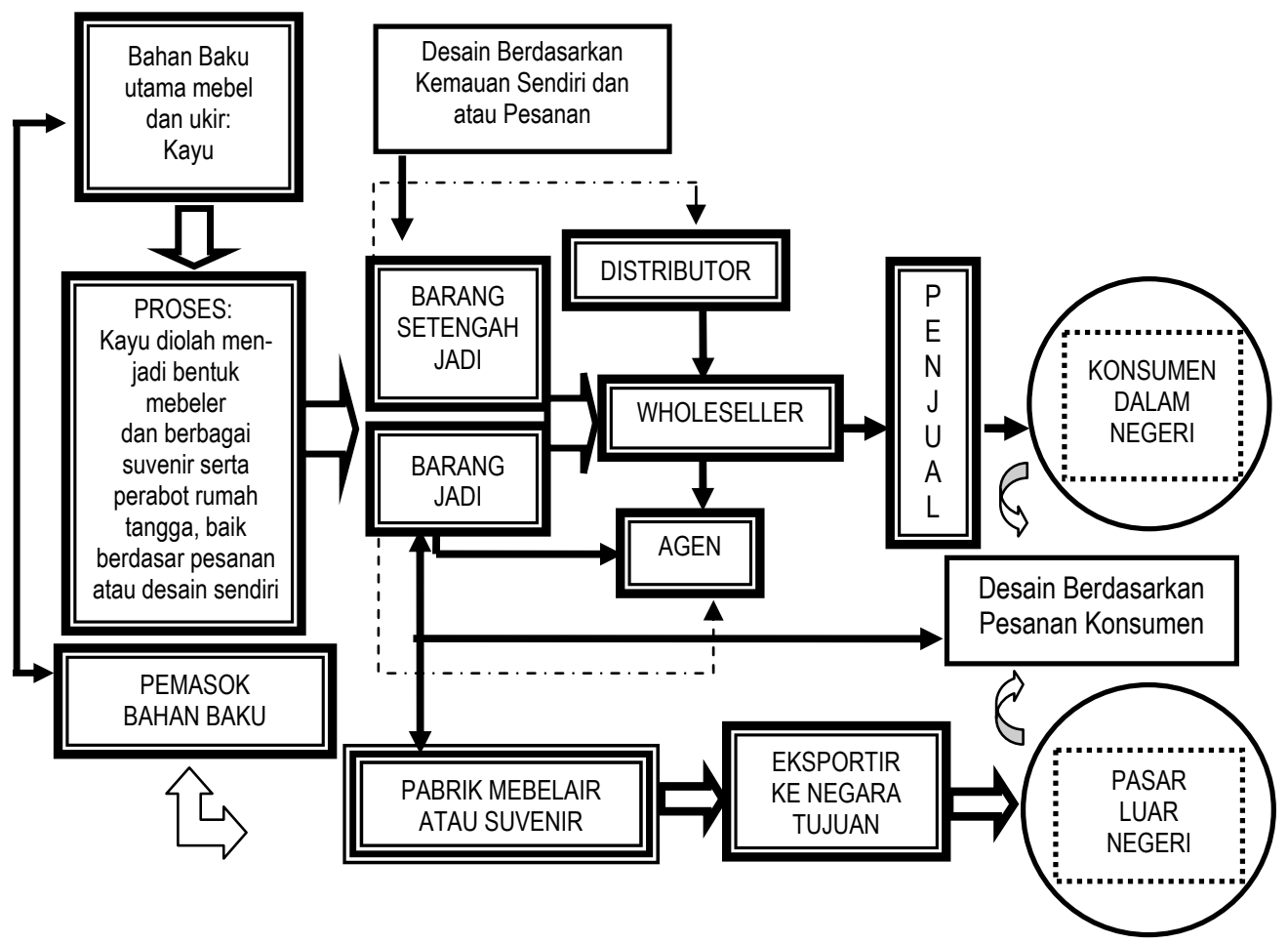

Gambar 1. Peta Rantai Nilai Produk UKM di Serenan, Klaten

Mengacu berbagai persoalan dan perkembangan serta rencana aksi kebijakan yang akan dikeluarkan pemerintah tentang industri perkayuan, maka dapat disusun sebuah matrik interaksi potensi dan lingkungan yang tampak pada Tabel 2, Tabel 3, dan Tabel 4.

Tabel 2. Matrik SWOT dari UKM Serenan, Klaten

\section{KEKUATAN (S)}

1. Ketersediaan bahan baku melimpah

2. Hampir semua masyarakat mengusahakan

3. Dukungan infrastruktur dan teknologi

4. Sifatnya yang padat karya

5. Keahlian turun temurun

PELUANG (0)

1. Kebutuhan - pasar yang semakin besar

2. Terbukanya peluang investasi

3. Implementasi otonomi daerah

4. Kebijakan yang pro usaha kecil kian luas

5. Kemudahan akses pasar internasional

\section{KELEMAHAN (W)}

1. Pola kemitraan yang belum optimal

2. Tidak ada proses - inovasi berlanjut

3. Aspek ketergantungan sangat kuat

4. Mata rantai distribusi yang bercabang

5. Dukungan permodalan yang minim

\section{ANCAMAN (T)}

1. Ancaman pencemaran lingkungan

2. Ancaman atas kerusakan ekosistem

3. Nilai tambah yang tidak optimal

4. Konflik kepentingan antar sesama

5. Instabilitas sosial - politik 
Tabel 3. Matrik Strategi SWOT untuk UKM di Serenan, Klaten

\begin{tabular}{|c|c|c|}
\hline \multirow{3}{*}{$\begin{array}{c}\text { Analisis } \\
\text { lingkungan } \\
\text { eksternal }\end{array}$} & KEKUATAN (S) & KELEMAHAN (W) \\
\hline & $\begin{array}{l}\text { 1. Ketersediaan bahan baku } \\
\text { melimpah } \\
\text { 2. Hampir semua masyarakat } \\
\text { mengusahakan } \\
\text { 3. Dukungan infrastruktur dan } \\
\text { tehnologi } \\
\text { 4. Sifat yang padat karya } \\
\text { 5. Keahlian turun temurun }\end{array}$ & $\begin{array}{l}\text { 1. Pola kemitraan yang belum optimal } \\
\text { 2. Tidak ada proses - inovasi } \\
\text { berlanjut } \\
\text { 3. Aspek ketergantungan sangat kuat } \\
\text { 4. Mata rantai distribusi yang } \\
\text { 5. Dukungan permodalan yang minim }\end{array}$ \\
\hline & $\begin{array}{l}\text { Strategi Menggunakan Kekuatan } \\
\text { untuk Memanfaatkan Kesempatan }\end{array}$ & $\begin{array}{c}\text { Strategi Mengurangi Kelemahan } \\
\text { dengan Memanfaatkan Kesempatan }\end{array}$ \\
\hline \multicolumn{3}{|l|}{ PELUANG (0) } \\
\hline \multirow{2}{*}{$\begin{array}{ll}\text { 1. } & \text { Kebutuhan - pasar yang } \\
& \text { semakin besar } \\
\text { 2. } & \text { Terbukanya peluang investasi } \\
\text { 3. Implementasi otonomi daerah } \\
\text { 4. } & \text { Kebijakan yang pro usaha kecil } \\
& \text { kian luas } \\
\text { 5. } & \text { Kemudahan akses pasar } \\
& \text { internasional }\end{array}$} & $\begin{array}{l}\text { STRATEGI } 1 \\
\text { STRATEGI } 2 \\
\text { STRATEGI } 3\end{array}$ & $\begin{array}{l}\text { STRATEGI } 5 \\
\text { STRATEGI } 6 \\
\text { STRATEGI } 7\end{array}$ \\
\hline & $\begin{array}{l}\text { Strategi Menggunakan Kekuatan } \\
\text { untuk Mencegah Ancaman }\end{array}$ & $\begin{array}{l}\text { Strategi Mengurangi Kelemahan } \\
\text { dengan Mencegah Ancaman }\end{array}$ \\
\hline \multicolumn{3}{|l|}{ ANCAMAN (T) } \\
\hline 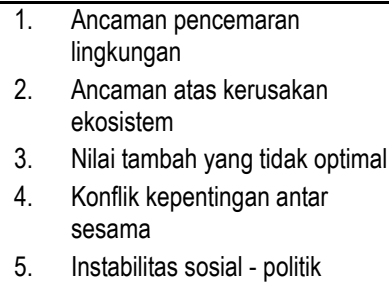 & STRATEGI 4 & STRATEGI 4 \\
\hline
\end{tabular}

Tabel 4. Strategi SWOT untuk UKM di Serenan, Klaten

\section{STRATEGI}

KETERANGAN

\footnotetext{
Strategi 1 Pengembangan investasi yang berorientasi ekspor dan berwawasan lingkungan.

Strategi 2 Peningkatan pengelolaan sumber daya alam dan pemberdayaan SDM.

Strategi 3 Pengembangan infrastruktur pendukung investasi dan sarana pendukungnya.

Strategi 4 Pencegahan kerawanan sosial dengan meningkatkan kemampuan SDM dan proses penciptaan lapangan kerja.

Strategi 5 Penatagunaan lahan dengan arah kebijakan pengendalian perijinan bagi penggunaan lahan secara sistematis dan berkelanjutan.

Strategi 6 Pengembangan jaringan distribusi produk lokal dan networking pasar global-ekspor

Strategi 7 Pengembangan Program Kemitraan secara sistematis dan berkelanjutan.
} 


\section{KESIMPULAN}

- Firm size: umumnya berskala kecil dan tradisional, mayoritas tidak berbadan usaha yang sempurna, meski ada sebagian yang telah menerapkan dan untuk usaha yang baru berdiri ternyata muncul karena lapangan kerja yang minim.

- Permodalan: mayoritas dari modal sendiri dan cenderung kecil. Ada sebagian yang berasal dari bank, tetapi sangat kecil.

- Perencanaan: belum punya perencanaan yang spesifik untuk kepentingan jangka panjang dan perencanaan yang ada sering bersifat intuisi, cenderung melemah karena keterbatasan modal. Konsekuensi tidak ada proses untuk ekspansi bisnis.

- Pemasaran: bersifat tradisional lebih mengandalkan model "getok tular" (dari mulut ke mulut). Meski ada website tapi tak optimal memanfaatkan. Aspek lokasi juga menjadi batasan bagi proses pemasaran, meski ini tidak mutlak.

- Produksi: mayoritas pesanan, terutama order eksportir. Untuk pesanan bahwa tipe dan jenis produk sudah standar sesuai permintaan dari mitra bisnis (program kemitraan) atau eksportir yang membawa contoh. Kualitas kontrol sangat ketat dan tidak jarang banyak terjadi pengembalian yang secara otomatis merugikan. Tidak ada inovasi yang radikal terhadap proses produksi, semuanya berjalan sesuai rutin (cenderung reaktif terhadap kemungkinan inovasi produk).

- Personalia: mengutamakan peran keluarga. Aspek profesionalisme seperti yang ada dalam organiasi formal tidak muncul dan cenderung tak berkembang. Tidak ada aturan yang jelas - spesifik atas deskripsi pekerjaan, semuanya tergantung pada kesiapan masing-masing untuk bekerja sesuai kesempatan yang ada pada saat itu. Semua bertanggungjawab atas kualitas produk, pemasaran, produksi, perencanaan, dan terutama kelangsungan hidup usaha

- Akses informasi: tak ada akses informasi, bila ada cenderung lemah dan tidak memanfaatkan secara total. Padahal, internet bisa dimanfaatkan untuk membuka peluang lebih terbuka, termasuk tujuan ekspor. Ada kesadaran atas informasi, tapi tidak ada komitmen untuk memanfaatkan secara penuh.

- Kinerja ekspor: mayoritas sangat tergantung pengepul atau eksportir dan tidak ada usaha untuk menembus langsung ke pasar ekspor. Beberapa memang sudah sering mengikuti pameran terutama untuk menarik buyer, tetapi ketakutan atas larinya buyer masih kuat. Sudah ada koordinasi dan binaan dari dinas terkait, baik di daerah, wilayah atau pusat dalam menjembatani promosi ekspor, meski realisasi masih belum sepenuhnya maksimal.

Rekomendasi dan strategi pengembangan yang perlu diimplementasikan, baik untuk jangka pendek, menengah atau panjang yaitu menyangkut beberapa kegiatan teknis sebagai berikut:

- Diperlukan upaya perbaikan revitalisasi atas semua komponen-komponen peralatan proses produksi, guna upaya peningkatan efektifitas dan efisiensi. Hal ini terutama mengacu indikasi banyak 
peralatan yang dipergunakan tergolong usang (out of date) dan bercorak konvensional tradisional.

- Peningkatan dalam hal mutu produk secara sistematis dan berkelanjutan.

- Menjaga kontinuitas kualitas input produksi dari pemasok bahan baku.

- Peningkatan aktivitas promosional dibarengi dengan perbaikan dalam mutu secara integratif, promotif, sistematis dan berkelanjutan.

- Upaya membuka jaringan segmen pasar baru baik untuk wilayah domestik maupun ekspor.

- Peningkatan nilai kualitas SDM yang terlibat aktif dengan memperkenalkan inovasi maupun teknologi proses dan desain yang lebih berkualitas dan modern.

- Pengadaan Sistem Informasi Manajemen guna lebih menjangkau keterbukaan terhadap informasi pasar secara nasional dan global.

- Upaya diversifikasi produk berikut pengembangan lini produknya agar tidak kalah bersaing dengan produk sejenis di pasar.

- Menjaga peruntukan lahan bahan input produksi agar tidak termarjinalisasi oleh hal lain yang merugikan kepentingan peningkatan kesejahteraan.

- Pengembangan usaha dari aspek permodalan yang dibarengi kegiatan penelitian dan pengembangannya.

\section{DAFTAR PUSTAKA}

Akita, T dan A. Alisjahbana, (2002), Regional Income Inequality in Indonesia and the Initial Impact of the Economic Crisis. Bulletin of Indonesian Economic Studies 38 (2): 201-222.

Aminudin, T (2003), Studi Pengembangan Industri Kecil di Daerah Istimewa Yogyakarta, http://pl.lib.itb.ac.id, diakses tanggal 20 Juni 2003.

Ayyagari, M., (2003), Small and Medium Enterprises across the Globe, Policy Research Working Paper, Washington USA: the World Bank.

Devarajan, S., (2002), Goals for Development, Policy Research Working Paper, Washington USA: the World Bank.

Gradstein, M., (2003), Governance and Economic Growth, Policy Research Working Paper, Washington USA: The World Bank.

Murphy, D., (2000), Membangun Organisasi Rakyat, Jakarta: URM-Indonesia.

Nasution, A., (2003), Strategi Pembangunan Ekonomi Baru, Makalah Dipresentasikan pada Kongres ISEI XV di Malang, 13-15 Juli 2003.

Rahayu, SL (2005), Analisis Peranan Perusahaan Modal Ventura dalam Mengembangkan UKM di Indonesia, Kajian Ekonomi dan Keuangan, Edisi Khusus November 2005.

Sallatu, A.M dan Suhab, S (2003), Pemberdayaan Ekonomi Rakyat: Pergulatan Mewujudkan Keadilan Sosial di Era Destoda, Jurnal Analisis, Vol. 1, No.1, September 
Sugarmansyah, U., Dharmawan, Hartaya, Ruki Savianto, Irawan Santoso (2003), Analisis Difusi Inovasi Teknologi Pengecoran Logam di Industri Kecil dan Menengah Klaten - Ceper: Tinjauan dari Aspek Kebijakan, http://www. iptek.net.id, diakses pada tanggal 25 Agustus 2003.

Suriadinata, YS., Pramono, T, dan Kailani, IA (2001), Penelitian Penggunaan Tek- nologi Informasi dan Komunikasi oleh UKM Eksportir di Indonesia: Kasus di Medan, Bandar Lampung, Jakarta, Bandung, Yogyakarta, Surabaya, Denpasar dan Makasar, Indonesia: USAID.

Sanusi, Anwar (2004), Tingginya Parokialism Institusi: Sebuah Kasus Pengembangan Koperasi dan UKM Indonesia, INOVASI Vol.1/XVI/Agustus 2004 